\title{
Evaluation of the Antimicrobial Properties of the Ethanolic Extracts of some Medicinal Plant Seeds from South-West Nigeria
}

\author{
Ibironke A. Ajayi and Olusola Ojelere \\ Industrial Chemistry unit, Chemistry Department, Faculty of Science, University of Ibadan, Ibadan, Nigeria
}

\begin{abstract}
The present study was conducted to evaluate the antimicrobial properties of the ethanolic extracts of some medicinal plant seeds against some clinical pathogens. The medicinal plant seeds investigated were Canna bidentata, Ceasalpinia bunduc, Hunteria umbellata, Hydrocotyle asiata, Megaphrynium macrostarchyum, Perinari excelsa, Rauwolfia vomitoria, Solanum dasyphyllum, Cola millenii and Sphenocentrum jollyanum. And the micro-organisms used for the antimicrobial assay were seven clinical pathogens, four bacteria: Bacillus subtilis, Staphylococcus aureus, Escherichia coli, Pseudomonas aeruginosa, and three fungi: Aspergillus niger, Penicillium notatum, and Candida albican. The extraction of the bioactive component of the seeds was done by cold extraction using ethanol as solvent and the antimicrobial assay was carried out using agar well diffusion method. The ethanolic extracts of all the selected seeds were active against all tested pathogens with maximum antimicrobial activity observed in S. dassyphylum ranging from $26 \mathrm{~mm}$ to 19 $\mathrm{mm}$ and minimum in M. macrostachyum ranging from $20 \mathrm{~mm}$ to $12 \mathrm{~mm}$ at concentration range of $200 \mathrm{mg} / \mathrm{ml}$ to $25 \mathrm{mg} / \mathrm{ml}$. For minimum inhibitory concentration (MIC) at concentration of $12.25 \mathrm{mg} / \mathrm{ml} \mathrm{S}$. dassyphylum was active against Escherichia coli and Staphylococcus aureus at $25 \mathrm{mg} / \mathrm{ml}$ while S. jollyanum was active against Bacillus subtilis at $25 \mathrm{mg} / \mathrm{ml}$. The broad spectrum of the antimicrobial activities observed in this study is an indicative that the ethanolic extract of these plant seeds possess significant antibacterial and antifungal properties that could probably serve as antimicrobial agents in new drug formulation against pathogenic microoganisms.
\end{abstract}

Key words: Antimicrobial, medicinal seeds, MIC, ethanolic extracts

\section{Introduction}

An antimicrobial is a substance that kills or inhibits the growth of microbes such as bacteria, fungi and viruses. Antimicrobial drugs either kill microbes (microbicidal) or prevent the growth of microbes (microbistatic). Anti-microbial drugs play an important role in the treatment of many infectious diseases. Antimicrobials are given to weaken or kill some of the invading pathogens. Hopefully, the body tissues can then destroy the rest. Antimicrobial drugs are used in relatively low concentrations in or upon the bodies of organisms to prevent or treat specific infectious diseases without harming the host organism. The course of an infection is often linked to a race between the pathogen's ability to grow in the host tissue and the tissues ability to capture and destroy the invading pathogen. Despite, the wide availability of clinically useful antibiotics and semi-synthetic analogues, a continuing search for new anti-infective agents remains indispensable. Major drawbacks of these are of limited spectrum or serious side effects. Moreover, the combination of the genetic versatility of microbes and widespread overuse of antibiotics has led to increasing clinical resistance of previously sensitive microorganisms and the emergence of previously unknown infections. One of the possible strategies for finding new, anti-infective drugs could involve the search for compounds with structures widely different from those in current use. So plants can be a major source for search of new anti-infective agents.

Plants provide a variety of resources that contribute to the fundamental needs of human such as food, clothing and shelter. Among plants of economic importance are medicinal plants. Plants have been utilized as therapeutic agents since time immemorial in both organized and unorganized forms (Girach et al., 2003).The healing properties of many herbal medicines have been recognized in many ancient cultures. Medicinal plants have been the mainstay of traditional herbal medicine amongst rural dwellers worldwide since antiquity to date. The therapeutic use of plants certainly goes back to the Sumerian and the Akkadian civilizations in about the third millenium BC. Hippocrates (ca. 460-377 BC). Natural products have been an integral part of the ancient traditional medicine systems, e.g. Chinese, Ayurvedic and Egyptian (Sarker \& Nahar 2007). Traditional medicine has and still remains the main source of therapy for a large majority of people in Nigeria for treating health problems and traditional medicine consultancy as well as consumption of the medicinal plants has a much lower cost than modern medicine. Traditional medicine is used throughout the world as it is dependent on locally available plants, which are easily accessible, and capitalizes on traditional wisdom-repository of knowledge, simple to use and affordable (Tesfaye \& Sebsebe 2009). The traditional methods, especially the use of medicinal plants, still play a vital role to cover the basic health needs in the developing countries and moreover, the use of herbal remedies has increased in the developed countries in the last decades. 
Medicinal plants have been known for their healing and disease-curing qualities for centuries. Some drugs of plant origin used in conventional medical practice are direct plant extracts or plant materials that have been suitably prepared and standardized (Donald 1986). The use of plant and its products has a long history that began with folk medicine and through the years has been incorporated into traditional and allopathic medicine (Dubey et al., 2011). Since antiquity, many plants species have been reported to have pharmacological properties as they are known to possess various secondary metabolites like glycosides, saponins, flavonoids, steroids, tannins, alkaloids, terpenes which are therefore, should be utilized to combat the disease causing pathogens (Kamali \& Amir 2010). Nowourdays, throughout the world, infectious diseases accounts for high proportion of health problems. Mortality due to these infections continues to be a major problem, especially amongst children. Infections due to a variety of bacterial etiologic agents, such as pathogenic Escherichia coli, Staphylococcus aureus and Enterobacter sp. are most common (Mukherjee et al., 1998). Many readily available plants in Nigeria are used in traditional folklore medicine for the treatment of several infections including typhoid fever and gastrointestinal disorders such as cholera, diarrhea and dysentery. Though large numbers of plants are constantly being screened for their antimicrobial effects yet, more pharmacological investigations are necessary (Pankaj et al., 2008). Therefore, the current study was designed to evaluate the antimicrobial properties of some medicinal plant seeds which have been traditionally used in the treatment of various infections against some selected bacteria and fungi pathogens frequently involved in severe infections in humans. This in continuation of the report by Ajayi and Ojelere (2013) on the chemical composition of the medicinal seeds that are been investigated in this study.

\section{Collection and Identification of Plant}

\section{Material and Methods}

Fresh ten different plant seeds viz., Hydrocotyle asiata, Hunteria umbellata, Megaphrynium macrostarchyum, Perinari excelsa, Solanum dassyphylum, Canna bidentata, Ceasalpinia bunduc, Rauwolfia vomitoria, Cola millenii and Sphenocentrum jollyanum free from disease were purchased from Ojee market in Ibadan North-East local Government, Oyo state, Nigeria. The plant seeds were identified and authenticated at Herbarium Unit of Botany Department, University of Ibadan, Oyo state, Nigeria. The seeds were air-dried and screened to remove undesirable materials such as stones and other impurities, after which they were dehulled, milled into powder and the powder kept in an airtight polythene bags until needed for analysis.

\section{Collection of Microorganisms}

Four clinical bacteria isolates made up of two gram-positive (Staphylococcus aureus, Escherichia coli), two gram-negative (Pseudomonas aeruginosa and Bacillus subtilis) were used for the antibacterial assay and three fungi (Candida albicans, Penicillium notatum and Aspergillus niger) were used for the antifungal assay. All the organisms were pure isolates obtained from the Laboratory stock culture unit of the Department of Pharmacological Microbiology, Faculty of Medicine, University of Ibadan, Oyo State, Nigeria.

\section{Preparation of plant extracts}

The ethanolic extract of the seeds was obtained by using the method previously described by (Owolabi et al., 2007). 100g of the powdered sample was soaked in $400 \mathrm{ml}$ of solvent in a sterile conical flask and covered with cotton wool. It was then plugged and wrapped with aluminum foil and shaken vigorously. The mixture was left to stand for 72 hours at room temperature of $25{ }^{\circ} \mathrm{C}$. The mixture was then filtered using Whatman No. 1 filter paper. Thereafter, the filtrate was evaporated to dryness by means of a rotary evaporator attached to a vacuum pump. The extracts were stored in refrigerator until needed for further analysis.

\section{Determination of antimicrobial activity}

The antimicrobial activity of selected plant seeds against clinical pathogens was determined by using agar well diffusion method based on the guidelines of the National Committee for Clinical Laboratory Standards (NCCLS 2002). Sterile nutrient agar plates were prepared for bacterial strains and Sterile Sabouraud's dextrose agar (SDA) were prepared for fungal strains inoculated by a spread plate method under aseptic conditions. 20 $\mathrm{ml}$ of sterilized nutrient agar was poured into Petri dishes and allowed for solidification. After solidification, 24 hours nutrient broth grown pathogenic cultures were swabbed on the respective agar plates using sterilized cotton swabs. Wells of $6 \mathrm{~mm}$ diameter were punched over the agar plates using a sterile gel puncher. About 100 $\mu \mathrm{l}$ of different concentrations of plant solvent extracts were added using sterile syringe into the wells and allowed to diffuse at room temperature for 1 hour and the plates were incubated at $37^{\circ} \mathrm{C}$ for $18-24$ hours for bacterial pathogens and $28{ }^{\circ} \mathrm{C}$ for 48 hours fungal pathogens respectively. After incubation, the diameter of inhibition zones formed around each wells were measured and expressed in millimeter ( $\mathrm{mm}$ ) and recorded against the corresponding concentrations to evaluate the antimicrobial activity. Positive controls were set using standard antibiotics drugs (Gentamycin) while negative controls were set using ethanol. 


\section{Determination of minimum inhibition concentration (MIC)}

The most sensitive plant seeds extracts were used in the MIC (bacteriostatic concentration) determination using well diffusion method. The inoculum of microorganisms was prepared from 18 hours nutrient broth cultures. In this method, the broth dilution technique was utilized where the plant extract was prepared to the highest concentration of $200 \mathrm{mg} / \mathrm{ml}$ (stock concentration) in ethanol and serially diluted to a working concentration ranging from $200 \mathrm{mg} / \mathrm{ml}$ to $6.25 \mathrm{mg} / \mathrm{ml}$ using Nutrient Agar and later inoculated with 1 $\mathrm{ml}$ suspension of the test organisms. The positive control was Nutrient Agar with standard reference antibiotics (Gentamycin) and inoculums. After $18-24$ hours of incubation at $37{ }^{\circ} \mathrm{C}$ for bacterial pathogens and 48 hours at $28{ }^{\circ} \mathrm{C}$ for fungal pathogens, the test tubes were observed for turbidity. All the experiments were done in triplicates.

\section{Result and Discussion}

The scientific, family, English and local names of the seeds investigated are listed on Table 1. Medicinal plants are very important and widely available resource for primary and complementary healthcare systems. It has been reported in literature that plant kingdom contains many species of plants harboring substances of medicinal value that are yet to be discovered. Though large numbers of plants are constantly being screened for their antimicrobial effects yet, more pharmacological investigations are necessary (Pankaj et al., 2008). The present study revealed the antimicrobial activity of ethanolic extracts of some medicinal plant seeds from South-west, Nigeria against some selected clinical pathogens such as B. subtilis, E. coli, S. aureus, P. aeruginosa, P. notatum, A. niger and C. albicans by agar well diffusion method. All the examined plant extracts showed varying degrees of antimicrobial activities against the clinical pathogens tested. The antimicrobial activity of ethanol extracts of these seeds were observed to be dosage-dependent and the activity varies with concentration against tested pathogens as shown in table 2 and minimum inhibitory concentration (MIC) as shown in table 3 was observed only in the plant extracts with strong inhibitory effect of antimicrobial activities. Despite what many researchers have reported that C. albicans are very resistant fungi, this work demonstrated that ethanolic extract of all the selected seeds were effective against this pathogenic fungi at concentration of $200 \mathrm{mg} / \mathrm{ml}$ and $100 \mathrm{mg} / \mathrm{ml}$ respectively. This result is in agreement with the report of Pavendan \& Sebastian (2012) on the leaf extract of E. singampattiana which was very effective on C. albicans. The ethanol extract of S. dassyphylum seeds was observed to show highest antimicrobial activity among the plant seeds extracts investigated in which all the serial diluted concentration were active against the tested pathogen except in C. albicans which was resistant to the extract at concentration of $25 \mathrm{mg} / \mathrm{ml}$, with minimum MIC of $12.25 \mathrm{mg} / \mathrm{ml}$ against E. coli and $25 \mathrm{mg} / \mathrm{ml}$ against S. aureus. P. excelsa extracts was observed to show good activity just like S. dassyphylum, with maximum zone of inhibition $(26 \mathrm{~mm})$ against C. albicans and lowest inhibitory zone of $16 \mathrm{~mm}$ against A. niger at concentration of $200 \mathrm{mg} / \mathrm{ml}$ with lower concentration showing little effect against the tested pathogens. This activity was observed to be within the range of activity showed by P. excelsa according to Stephen \& Joseph (2011). H. unbellata and H. asiata seeds extracts were observed to have comparatively similar activity against the selected pathogen with maximum inhibitory zone of $22 \mathrm{~mm}$ and $20 \mathrm{~mm}$ with the same minimum zone of inhibition of $16 \mathrm{~mm}$ at the concentration of $200 \mathrm{mg} / \mathrm{ml}$ with MIC of $100 \mathrm{mg} / \mathrm{ml}$ in H. asiata.

The ethanolic extract of $C$. bidentata showed maximum zone of inhibition $(21 \mathrm{~mm})$ against $C$. albicans. Also, minimum inhibitory zone $(12 \mathrm{~mm})$ was exhibited against $\mathrm{P}$. aeruginosa and $\mathrm{S}$. aureus at the same concentration of $200 \mathrm{mg} / \mathrm{ml}$. The extract of C. bidentata was observed to show no reasonable inhibition against S. aureus, P. notatum and C. albicans at concentration of $100 \mathrm{mg} / \mathrm{ml}$ and bellow. For C. millenii seeds extracts maximum zone of inhibition $(19 \mathrm{~mm})$ was observed against B. subtilis and C. albicans, and minimum inhibitory zone $(15 \mathrm{~mm})$ was shown against $\mathrm{S}$. aureus while B. subtilis, P. notatum and C. albicans were resistant to the extract at the concentration of $50 \mathrm{mg} / \mathrm{ml}$ and below with minimum inhibitory concentration (MIC) of $50 \mathrm{mg} / \mathrm{ml}$ against P. aeruginosa and Escherichia coli, which was observed to be more active than the report of Giwa et al., (2012)in which some of the microbes were resistant to the plant extract. S. jollyanum was observed to show good antimicrobial activity in which almost all the serial diluted concentration were active against the tested pathogen except in P. notatum at concentration of $50 \mathrm{mg} / \mathrm{ml}$, with minimum MIC of $25 \mathrm{mg} / \mathrm{ml}$ against B. subtilis. C. bunduc and R. vomitoria were also observed to show good inhibitory effect against the tested organisms, the activity was observed to depend on the concentration of the extracts with minimum inhibitory concentration of $50 \mathrm{mg} / \mathrm{ml}$ observes in C. bunduc against S. aureus. M. macrostachyum seeds extract was observed to show least activity among the investigated seeds with maximum zone of inhibition of $20 \mathrm{~mm}$ and the lower concentrations were not as active as expected. Some the investigated seeds such as S. dassyphylum, P. excelsa and S. jollyanum were observed to be more active than the control drug gentamycin at the concentration of $200 \mathrm{mg} / \mathrm{ml}$. Generally, S. dassyphylum has the highest antimicrobial activity with maximum zone of inhibition of $26 \mathrm{~mm}$ while M.macrostachyum has the lowest activity with maximum zone of inhibition of 20 $\mathrm{mm}$. The implication of the broad spectrum action of some of these extracts is that they can be useful in antiseptic and disinfectant formulation as well as in chemotherapy if the active principle can be isolated (Olukoya et al., 1993). The results of this study showed that the extraction of antimicrobial substances by 
organic solvents is better when compared to aqueous extracts which suggests that ethanol is more effective solvent for extracting the bioactive compounds from the seeds.

The polarity of antibacterial compounds make them more readily extracted by organic solvents, and using organic solvents does not negatively affect their bioactivity against pathogenic bacteria species (Thongson et al., 2004). The outcome of this work is a good evidence to validate the use of these seeds in traditional folklore medicine for the treatment of several infections including typhoid fever and gastrointestinal disorders such as cholera, diarrhea and dysentery in Nigeria.

\section{Conclusion}

All the medicinal plants seeds investigated in this study exhibited reasonable degrees of antimicrobial properties against the clinical pathogens tested as revealed by the broad spectrum of the zone of inhibition and minimum inhibitory concentration. Our findings revealed that the ethanolic extracts of these plant seeds possess compounds with antimicrobial properties that could probably be used as antimicrobial agents in new drugs development.

\section{Acknowledgements}

The authors thank the Department of Chemistry, Faculty of Science and Department of Pharmacological Microbiology, Faculty of Medicine both of University of Ibadan, for making their facilities available.

\section{Refrences}

[1]. Ajayi, I. A. \& Ojelere, O.O. (2013) Chemical composition of ten medicinal plant seeds from Southwest Nigeria, Advances in Life Science and Technology. 10: 25-32.

[2]. Donald, E.U. (1986). Medicinal plants research in Nigeria: Retrospect and Prospects. In: Sofowora A, Ed. The State of Medicinal Plants Research in Nigeria. Nigerian Society of Pharmacognosy, Ibadan University Press, Nigeria, pp 1-12.

[3]. Dubey, R., Dubey, K., Sridhar, C.\& Jayaveera, K.N. (2011). Human vaginal pathogen inhibition studies on aqueous, methanolic and saponins extracts of stem barks of ziziphus mauritiana. Int. J. Pharm. Sci. Res. 2(3): 659-663.

[4]. Girach, R.D., Khan, H. and Ahmad, M. (2003). Botanical identification of Thuhar, seldom used as Unani medicine. Hamdard Medicus. 96 (1): 27-33.

[5]. Giwa O. E., Onileke F. O., Adesina I. A. \& Adebote V. T (2012). Phytochemical and antimicrobial properties of seed and pulp of monkey cola (cola millenii) on some selected clinical and food borne isolate, International Journal of Applied Biology and Pharmaceutical Technology. 3(3): 390-400.

[6]. Kamali Hhel \& Amir Myel (2010). Antibacterial Activity and Phytochemical Screening of Ethanolic Extracts Obtained from Selected Sudanese Medicinal Plants. Curr. Res. J. of Bio. Sci. 2(2): 143-146.

[7]. Mukherjee, P.K., Saha, K., Murugesan, T., Mandal, S.C., Pal, M. \& Saha, B.P., (1998). Screening of anti-diarrheal profile of some plant extracts of a specific region of West Bengal, India. J. Ethnopharmacol, 60: 85- 89.

[8]. NCCLS. (2002). Performance standards for antimicrobial disk susceptibility testing, 12th informational supplement. NCCLS document, M100-S12. National Committee for Clinical Laboratory Standards, Wayne, Pa.

[9]. Olukoya, D.K., Ndika, N., Odugbemi ,T.O. (1993). Antibacterial activity of some medicinal plants in Nigeria. Journal of Ethnopharmacology. 39: 69-72.

[10]. Owolabi, O. J., Omogbai, E. \& Obasuyi, O. (2007). Antifungal and antibacterial activities of the ethanolic and aqueous extracts of Kigelia Africana (Bignoniaceae) stem bark. Afr. J. Biotechnol. 6(14): 1677-1680.

[11]. Pankaj Goyal, Arjun Khanna, Abhishek Chauhan, Garima Chauhan \& Purshotam Kaushik (2008). In vitro evaluation of crude extracts of Catharanthus roseus for potential antibacterial activity. International Journal of Green Pharmacy 2(3): 176-18.

[12]. Pavendan, P. \& Sebastian Rajasekaran, C. (2012).Evaluation of the Antimicrobial Activity of Eugenia singampattiana Bedd. Endangered Medicinal Plant leaves extract. International Journal of PharmTech Research. 4 (1):476-480.

[13]. Sarker, S.D. \& Nahar, L. (2007). Chemistry for Pharmacy Students General, Organic and Natural Product Chemistry. England: John Wiley and Sons. pp 283-359.

[14]. Stephen, A. E. \& Joseph, E. E. (2011). Antimicrobial, nutritional and phytochemical properties of Perinari excelsa seeds. International Journal of Pharma and Bio Sciences. 2: 459-470.

[15]. Tesfaye Awas \& Sebsebe Demissew(2009). Ethnobotanical study of medicinal plants in Kafficho people, southwestern Ethiopia In: Proceedings of the 16th International Conference of Ethiopian Studies.

[16]. Thongson, C., Davidson, P.M., Mahakarnchanakul, W. \& Weiss, J. (2004).Antimicrobial activity of ultrasound-assisted solventextracted spices. Lett Appl Microbiol. 39:401-406.

Table 1: Scientific, Family, English and Local names of the seeds investigated ${ }^{\text {a }}$

\begin{tabular}{|l|l|l|l|}
\hline Scientific Name & Family Name & English Name & Local Name \\
\hline Canna bidentata & Cannaceae & NA & Ido \\
\hline Ceasalpinia bunduc & Fabaceae & Gray Nicker Nut & Ayo \\
\hline Cola millenii & Sterculiaceae & Monkey Kola & Obi Edun \\
\hline Hunteria umbellata & Apocynaceae & NA & Abeere \\
\hline Hydrocotyle asiata & Sterculiaceae & Memory nut & Obi Awogba arun \\
\hline Megaphrynium macrostarchyum & Marantaceae & NA & Gbodogi \\
\hline Perinari excelsa & Chrysobalanaceae & Grey plum & Yinrinyinrin \\
\hline Rauwolfia vomitoria & Apocynaceae & Poison devil's pepper & Asofeyeje \\
\hline Solanum dasyphyllum & Sterculiaceae & NA & Bamoni \\
\hline Sphenocentrum jollyanum & Menispermaceae & Dog's penis & Akerejupon \\
\hline
\end{tabular}


$\mathrm{NA}=$ Not available

${ }^{a}$ Ajayi \&Ojelere, 2013

Table 2: Antimicrobial activity of the ethanolic extracts of the selected seeds on isolated pathogens

\begin{tabular}{|c|c|c|c|c|c|}
\hline \multirow[t]{3}{*}{ Isolated bacteria and fungi } & \multicolumn{4}{|c|}{ Concentration in $(\mathrm{mg} / \mathrm{ml})$} & \multirow{2}{*}{$\begin{array}{l}\text { Gentamycin } \\
10 \mu \mathrm{g} / \mathrm{ml}\end{array}$} \\
\hline & 200 & 100 & 50 & 25 & \\
\hline & \multicolumn{5}{|c|}{ P.excelsa seeds extract, zone ,of inhibition in (mm) } \\
\hline Bacillus subtilis & 18 & 16 & 15 & 12 & 23 \\
\hline Staphylococcus aureus & 22 & 18 & 17 & 14 & 21 \\
\hline Pseudomonas aeruginosa & 17 & 15 & 13 & 10 & 20 \\
\hline Escherichia coli & 20 & 18 & 17 & 16 & 23 \\
\hline Aspergillus niger & 16 & - & - & - & 19 \\
\hline Penicillium notatum & 20 & 18 & - & - & 20 \\
\hline \multirow[t]{2}{*}{ Candida albicans } & 26 & 18 & - & - & 19 \\
\hline & \multicolumn{5}{|c|}{ H. unbellata seeds extract, zone of inhibition in (mm) } \\
\hline Bacillus subtilis & 22 & 18 & 16 & 12 & 24 \\
\hline Staphylococcus aureus & 18 & 15 & - & - & 20 \\
\hline Pseudomonas aeruginosa & 16 & 14 & - & - & 18 \\
\hline Escherichia coli & 19 & 17 & 13 & - & 23 \\
\hline Aspergillus niger & 18 & 15 & - & - & 19 \\
\hline Penicillium notatum & 17 & 15 & 13 & - & 20 \\
\hline Candida albicans & 19 & 15 & - & - & 21 \\
\hline
\end{tabular}

Candida albicans

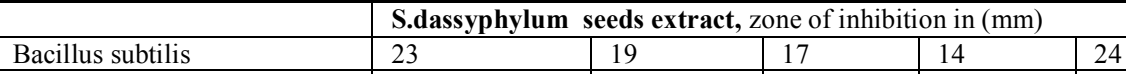

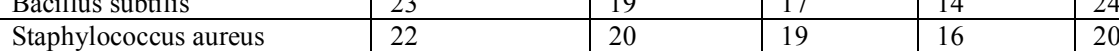

\begin{tabular}{l|l|l|l|l|l}
\hline Pseudomonas aeruginosa & 19 & 20 & 19 & 16 & 20 \\
\hline
\end{tabular}

\begin{tabular}{|l|l|l|l|l|l|}
\hline Escherichia coli & 26 & 23 & 20 & 18 & 23 \\
\hline
\end{tabular}

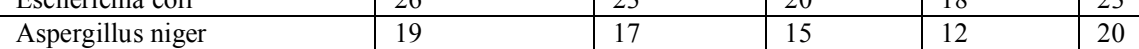

\begin{tabular}{|l|l|l|l|l|l}
\hline Penicillium notatum & 25 & 22 & 17 & 14 & 21 \\
\hline Candida albicans & 26 & 23 & 19 & - & 21
\end{tabular}

\begin{tabular}{l|l} 
H.asiata seeds extract, zone of inhibition in (mm) \\
\hline
\end{tabular}

\begin{tabular}{|l|l|l|l|l|l|}
\hline Bacillus subtilis & 20 & 18 & 16 & 14 & 23 \\
\hline
\end{tabular}

\begin{tabular}{|l|l|l|l|l|l|}
\hline Staphylococcus aureus & 16 & 15 & 13 & 10 & 20 \\
\hline Pseudomonas aeruginosa & 18 & 16 & 13 & 10 & 19 \\
\hline Escherichia coli & 20 & 17 & 14 & 11 & 22 \\
\hline Aspergillus niger & 16 & 14 & 13 & 10 & 19 \\
\hline Penicillium notatum & 18 & 16 & 13 & 12 & 20 \\
\hline Candida albicans & 20 & 16 & 12 & - & 21 \\
\hline
\end{tabular}

\begin{tabular}{|l|l|l|l|l|l|}
\hline & \multicolumn{4}{|l|}{ P.excelsa seeds extract, zone ,of inhibition in (mm) } \\
\hline Bacillus subtilis & 18 & 16 & 15 & 12 & 23 \\
\hline Staphylococcus aureus & 22 & 18 & 17 & 14 & 21 \\
\hline Pseudomonas aeruginosa & 17 & 15 & 13 & 10 & 20 \\
\hline Escherichia coli & 20 & 18 & 17 & 16 & 23 \\
\hline Aspergillus niger & 16 & - & - & - & 19 \\
\hline Penicillium notatum & 20 & 18 & - & - & 20 \\
\hline Candida albicans & 26 & 18 & - & - & 19 \\
\hline & H. unbellata seeds extract, zone of inhibition in (mm) & \multicolumn{1}{l}{} \\
\hline Bacillus subtilis & 22 & 18 & 16 & 12 & 24 \\
\hline Staphylococcus aureus & 18 & 15 & - & - & 20 \\
\hline Pseudomonas aeruginosa & 16 & 14 & - & - & 18 \\
\hline Escherichia coli & 19 & 17 & 13 & - & 23 \\
\hline Aspergillus niger & 18 & 15 & - & - & 19 \\
\hline Penicillium notatum & 17 & 15 & 13 & - & 20 \\
\hline Candida albicans & 19 & 15 & - & - & 21 \\
\hline
\end{tabular}

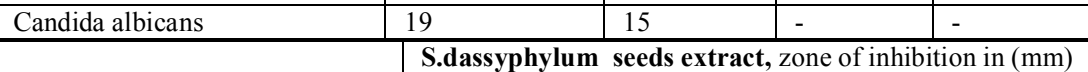

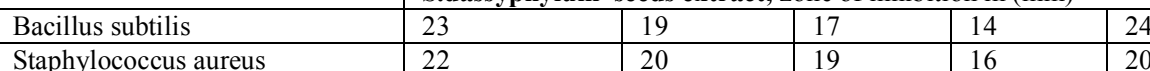

\begin{tabular}{l|l|l|l|l|l}
\hline Staphylococcus aureus & 22 & 20 & 19 & 16 & 20 \\
\hline Pseudomonas aeruginosa & 19 & 17 & 16 & 12 & 20
\end{tabular}

Pseudomonas aeruginosa

Escherichia coli

Aspergillus niger

Penicillium notatum

Candida albicans

Bacillus subtilis

Staphylococcus aureus

Pseudomonas aeruginosa

Escherichia coli

Aspergillus niger

Penicillium notatum

Candida albicans

25

\begin{tabular}{|l|l|l|l}
17 & 16 & 12 & 20 \\
\hline 23 & 20 & 18 & 23 \\
\hline 17 & 15 & 12 & 20
\end{tabular}

\begin{tabular}{l|l}
\hline 6 & 23 \\
\hline 9 & 17 \\
\hline
\end{tabular}

\begin{tabular}{|l|l}
\hline 5 & 22 \\
\hline 26 & 23 \\
\hline
\end{tabular}

\begin{tabular}{l|l|l}
22 & 17 & 14 \\
\hline 23 & 19 & -
\end{tabular}

\begin{tabular}{|l|l|l|l|l|}
\hline H.asiata seeds extract, zone of inhibition in $(\mathrm{mm})$ \\
\hline 20 & 18 & 16 & 14 & 23 \\
\hline 16 & 15 & 13 & 10 & 20 \\
\hline 18 & 16 & 13 & 10 & 19 \\
\hline 20 & 17 & 14 & 11 & 22 \\
\hline 16 & 14 & 13 & 10 & 19 \\
\hline 18 & 16 & 13 & 12 & 20 \\
\hline 20 & 16 & 12 & - & 21 \\
\hline
\end{tabular}




\begin{tabular}{|l|l|l|l|l|l|}
\cline { 2 - 6 } & \multicolumn{5}{l}{ M.macrostachyum seeds extract,zone of inhibition in (mm) } \\
\hline Bacillus subtilis & 17 & 13 & - & - & 23 \\
\hline Staphylococcus aureus & 12 & 10 & - & - & 20 \\
\hline Pseudomonas aeruginosa & 15 & - & - & - & 18 \\
\hline Escherichia coli & 16 & 14 & - & - & 22 \\
\hline Aspergillus niger & 18 & 16 & 15 & 11 & 19 \\
\hline Penicillium notatum & 20 & 15 & - & - & 20 \\
\hline Candida albicans & 20 & 16 & 12 & 10 & 21 \\
\hline & C. millenii seeds extract, zone of inhibition in (mm) \\
\hline Bacillus subtilis & 19 & 14 & - & - & 24 \\
\hline Staphylococcus aureus & 15 & 13 & 10 & - & 20 \\
\hline Pseudomonas aeruginosa & 17 & 15 & 13 & 10 & 18 \\
\hline Escherichia coli & 18 & 16 & 10 & - & 23 \\
\hline Aspergillus niger & 17 & 13 & 10 & - & 19 \\
\hline Penicillium notatum & 16 & 14 & - & - & 20 \\
\hline Candida albicans & 19 & 15 & - & - & 21 \\
\hline
\end{tabular}

Table 3: Minimum Inhibitory concentration (MIC) of ethanolic extracts of the selected seeds on isolated pathogens at different concentration in $(\mathrm{mg} / \mathrm{ml})$

\begin{tabular}{|c|c|c|c|c|c|c|c|}
\hline \multirow[t]{2}{*}{ Isolated bacteria and fungi } & \multirow{2}{*}{$\begin{array}{l}\text { Concentration in }(\mathrm{mg} / \mathrm{ml}) \\
200\end{array}$} & \multirow{2}{*}{$\begin{array}{l}\mathrm{MIC} \\
100 \\
\end{array}$} & \\
\hline & & & 50 & 25 & 12.5 & 6.25 & \\
\hline & S.dassyphylum seeds extract, MIC & & & & & & \\
\hline Bacillus subtilis & - & - & + & + & + & + & 100 \\
\hline Staphylococcus aureus & - & - & - & - & + & + & 25 \\
\hline Pseudomonas aeruginosa & - & + & + & + & + & + & 200 \\
\hline Escherichia coli & - & - & - & - & - & + & 12.25 \\
\hline Aspergillus niger & - & - & + & + & + & + & 100 \\
\hline Penicillium notatum & - & + & + & + & + & + & 200 \\
\hline \multirow[t]{2}{*}{ Candida albicans } & - & - & + & + & + & + & 100 \\
\hline & P.excelsa seeds extract ,MIC & & & & & & \\
\hline Bacillus subtilis & - & - & + & + & + & + & 100 \\
\hline Staphylococcus aureus & - & - & - & + & + & + & 50 \\
\hline Pseudomonas aeruginosa & - & - & + & + & + & + & 100 \\
\hline Escherichia coli & - & - & - & + & + & + & 50 \\
\hline Aspergillus niger & + & + & + & + & + & + & ND \\
\hline Penicillium notatum & - & + & + & + & + & + & 200 \\
\hline \multirow[t]{2}{*}{ Candida albicans } & - & - & + & + & + & + & 100 \\
\hline & H.asiata seeds extract, MIC & & & & & & \\
\hline Bacillus subtilis & 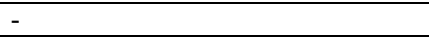 & + & + & + & + & + & 200 \\
\hline Staphylococcus aureus & - & + & + & + & + & + & 200 \\
\hline Pseudomonas aeruginosa & - & - & + & + & + & + & 100 \\
\hline Escherichia coli & - & - & + & + & + & + & 100 \\
\hline Aspergillus niger & - & + & + & + & + & + & 200 \\
\hline Penicillium notatum & - & - & + & + & + & + & 100 \\
\hline \multirow[t]{2}{*}{ Candida albicans } & - & - & + & + & + & + & 100 \\
\hline & S. jollyanum seeds extract, MIC & & & & & & \\
\hline Bacillus subtilis & - & - & - & - & + & + & 25 \\
\hline Staphylococcus aureus & - & - & + & + & + & + & 100 \\
\hline Pseudomonas aeruginosa & - & + & + & + & + & + & 200 \\
\hline Escherichia coli & - & - & - & + & + & + & 50 \\
\hline Aspergillus niger & - & - & + & + & + & + & 100 \\
\hline Penicillium notatum & - & + & + & + & + & + & 200 \\
\hline \multirow[t]{2}{*}{ Candida albicans } & - & - & + & + & + & + & 100 \\
\hline & C.bunduc seeds extract, MIC & & & & & & \\
\hline Bacillus subtilis & + & + & + & + & + & + & ND \\
\hline Staphylococcus aureus & - & - & - & + & + & + & 50 \\
\hline Pseudomonas aeruginosa & - & + & + & + & + & + & 200 \\
\hline Escherichia coli & - & - & + & + & + & + & 100 \\
\hline Aspergillus niger & - & + & + & + & + & + & 200 \\
\hline Penicillium notatum & + & + & + & + & + & + & ND \\
\hline \multirow[t]{2}{*}{ Candida albicans } & - & + & + & + & + & + & 200 \\
\hline & C. millenii seeds extract, MIC & & & & & & \\
\hline Bacillus subtilis & - & + & + & + & + & + & 200 \\
\hline Staphylococcus aureus & - & + & + & + & + & + & 200 \\
\hline Pseudomonas aeruginosa & - & - & - & + & + & + & 50 \\
\hline Escherichia coli & - & - & - & + & + & + & 50 \\
\hline Aspergillus niger & - & - & + & + & + & + & 100 \\
\hline Penicillium notatum & - & - & + & + & + & + & 100 \\
\hline Candida albicans & - & + & + & + & + & + & 200 \\
\hline
\end{tabular}

Growth; - No growth; ND Not Detected 